\title{
CORRELATION OF BLOOD CHOLESTEROL LEVELS AND HYPERTENSION WITH THE INCIDENCE OF STROKE IN THE PROVINCIAL HOSPITAL OF BANJARMASIN
}

\author{
Muhammad Saputra ${ }^{*}$, Candra Kusuma Negara ${ }^{2}$, Anna Martiana $^{3}$, Henny Puspasari ${ }^{3}$, \\ Akhmad Murjani ${ }^{4}$ \\ 1,2,3,4 Institute Of Health Science CahayaBangsa Banjarmasin \\ Email*: Putra.Muhammad07@gmail.com
}

\begin{abstract}
Introduction: Stroke risk factors are related to the circumstances of a person's health status, namely hypercholesterolemia (excess cholesterol levels) and hypertension (high blood pressure).Methods: A correlative descriptive analytic observational study using cross sectional approach. The number of samples taken is as many as 62 people using the Slovinformula..Statistical analysis uses Sperman Rank Test and Linear regression test.Results: The results of this study indicate that the total cholesterol level of patients from 62 samples found that normal cholesterol levels amounted to 29 people (46.8\%) consisting of 12 people (19.4\%) with SH and 17 people (27.4\%) with SNH and high cholesterol levels totaling 33 people (53.2\%) divided into 7 people (11.3\%) with SH and 26 people (42\%) with SNH. There is a significant correlation between blood cholesterol levels with stroke incidence in statistical tests with $p$ value 0,004 ( $p<0,05)$, there is a significant correlation between hypertension and stroke events withp value 0,031(p<0,05)there is no significant correlation between blood cholesterol levels and hypertension in statistical tests withp value 0,129 $(p>0,05)$ and by using Linear regression test obtained that the correlation between blood cholesterol levels with a value of mean value hypertension 0.453 and mean 0.994 so that the most dominant with the incidence of stroke was hypertension.Conclusions: Have nothing to do with hypertension, it can be concluded here that stroke is caused by hypertension. The Suggestion is hypertension's not only caused by cholesterol levels but there are other triggers that cause it.
\end{abstract}

Keywords: blood cholesterol levels; hypertension; incidence of stroke

\section{INTRODUCTION}

Stroke or cerebrovascular disease according to the World Health Organization (WHO) is clinical signs that develop rapidly due to focal or global brain function disorders due to blockage or rupture of blood vessels in the brain with symptoms lasting 24 hours or more (Arifianto, 2014) Meanwhile, according to Anies (2018) stroke is a condition that occurs when the blood supply to a part of the brain is suddenly interrupted, because some brain cells die by reason of disruption of blood flow caused by blockage or rupture of the blood vessels of the brain.Stroke is divided into two, hemorrhagic stroke and non-hemorrhagic stroke. Hemorrhagic stroke is bleeding that occurs due to rupture of blood vessels in certain brain regions and non-hemorrhagic strokes are interruption in part or overall blood flow to the brain due to blocked arteries (Anies, 2018).

Stroke has an impact on socioeconomic conditions due to the disability caused. Because the prevalence of stroke is increasing in Indonesia and the number one cause of disease. Identification of stroke risk factors is very useful forplanning preventive interventions. Variousstudies have succeeded in identifying risk factors for stroke such as hereditary, age, gender, socio-economic, geographical location or diet.In addition to the stroke risk factors above, there are still other risk factors that need to be considered by everyone both young and adult. These risk factors are related to the state of one's health status, namely hypercholesterolemia (excessive cholesterol levels) and hypertension (high blood pressure) (Anies, 2018).According toRahayu (2014) hypercholesterolemia (excess cholesterol levels) is also a risk factor for stroke in someone.Hypercholesterolemia is a condition that shows low levels of lipoprotein (LDL) in the blood that exceeds normal, so that it can lead to the formation of plaques in blood vessels which are getting more and more accumulated in that blood flow to the brain can be disrupted. If blood flow is disrupted, a stroke will occur.

According to Burhanudin (2012) hypertension (high blood pressure) is the most important risk factor based on the degree of risk of stroke. Whereas according to research Sorganvi et al (2014) hypertension is the greatest risk of stroke compared with family history of stroke and smoking status. Hypertension will spur the onset of plaque in 
large blood vessels (atherosclerosis). The appearance of plaque will narrow the lumen or diameter of the blood vessels. Unstable plaque will easily break and detach. Plaques that are released increase the risk of blocking the blood vessels of the brain that are smaller. When this happens, it will cause stroke.

The number of all stroke patients in the world at an international neuroscience conference in the UK reported that there were more than 1,000 stroke patients under the age of 30 years. The world health agency predicts that deaths from stroke will increase along with deaths from heart disease and cancer of about 6 million in 2010 to 8 million in 2030 (Burhanuddin, 2012). No exception in Indonesia, based on the Ministry of Health's Riskerdas data in 2013 showed an increase in stroke prevalence in Indonesia, from 8.3 per 1,000 population in 2007 to 12.1 per 1,000 population in 2013. While in 2020 it was estimated to 7.6 million people will die from strokes.

Globally the incidence of ischemic stroke is the highest reaching $87 \%$, then the stroke of intracerebral hemorrhage is $10 \%$ and the remaining $30 \%$ is a subarachnoid hemorrhagic stroke (Pandian et al, 2013). Based on the research by Endang (2011) the incidence of non-hemorrhagic stroke in Indonesia is much higher than hemorrhagic stroke, which is $67.1 \%$ compared to $32.9 \%$. The prevalence of stroke in the last 12 months in the province of South Kalimantan was 9.7 per 1000 population with a range of 5.2-18.5 thousand people (South Kalimantan Provincial Health Office, 2012).

\section{METHODS}

\section{Experiment Design}

Design of this study was a correlative study with a cross sectional approach, namely the type of research that measured the variables (independent variables and dependent variables) with just one time. This research was conducted in the inpatient room of Banjarmasin Hospital in June - July 2019.The population in this study was all stroke patients who were hospitalized at Banjarmasin Hospital from January 1, 2019 to April 30, 2019 as many as 166 people.The number of samples taken is as many as 62 people using the Slovin formula. The instrument used in this study uses a list of medical records of patients with stroke diagnoses that have been recorded for the past 4 months in the hospital.The sample is part of the number and characteristics possessed by the population. If large populations and researchers are not likely to learn everything in the population, for example because of limited funds, energy and time, researchers can use samples taken from the population. Using the Slovin formula with an error rate of $5 \%$ or 0.5 was found 62 People.Based on the research ethical feasibility statement No. 362 / II-Reg Research / RSUDU / 19 from the Research Ethics Commission of Ulin Hospital Banjarmasin, this research is ethical.This study has been conducted in hold principle of research ethics like anonymity, autonomy, veracity, beneficence, justice and informed consent also.

\section{RESULTS}

Table 1. Distribution of Respondent According to Demographic

\begin{tabular}{|c|c|c|}
\hline Characteristics & $\begin{array}{c}\text { Frequenc } \\
\text { y (n) }\end{array}$ & $\begin{array}{c}\text { Percentage } \\
(\%)\end{array}$ \\
\hline \multicolumn{3}{|l|}{ Gender } \\
\hline 1. Male & 26 & 41.9 \\
\hline 2. Female & 36 & 58.1 \\
\hline Total & 62 & 100 \\
\hline \multicolumn{3}{|l|}{ Age } \\
\hline $\begin{array}{l}\text { 1. } 36-45 \\
\text { years }\end{array}$ & 19 & 30.6 \\
\hline $\begin{array}{l}\text { 2. } 46-55 \\
\text { years }\end{array}$ & 21 & 38.9 \\
\hline $\begin{array}{l}\text { 3. } 56-65 \\
\text { years }\end{array}$ & 18 & 29.0 \\
\hline 4. Up to 65 & 4 & 6.5 \\
\hline Total & 62 & 100 \\
\hline
\end{tabular}

Table 2. Bivariate analysis 
1. Cross Tabulation and Sperman Rank statistical test results based on the Correlation between Blood Cholesterol Levels and Stroke Events

\begin{tabular}{|c|c|c|c|c|c|c|}
\hline \multirow{3}{*}{ Cholestrol } & \multicolumn{4}{|c|}{ Stroke } & \multirow[b]{2}{*}{ Total } & \multirow[b]{2}{*}{$\%$} \\
\hline & \multicolumn{2}{|r|}{ SH } & \multicolumn{2}{|c|}{ SNH } & & \\
\hline & $\mathbf{F}$ & $\%$ & $\mathbf{F}$ & $\%$ & & \\
\hline Normal & 12 & 19.4 & 17 & 27.4 & 29 & 48.6 \\
\hline High & 7 & 11.3 & 26 & 42 & 33 & 53.2 \\
\hline \multirow[t]{2}{*}{ Total } & 19 & 30.6 & 43 & 69.4 & 62 & 100 \\
\hline & \multicolumn{4}{|c|}{$\mathrm{p}=\mathbf{0 . 0 0 4}$} & \multicolumn{2}{|c|}{$R^{2} o_{x y}=0.359$} \\
\hline
\end{tabular}

2. Cross Tabulation and the results of the Spearman Rank statistical test based on the Correlation of Hypertension with Stroke Event

\begin{tabular}{|c|c|c|c|c|c|c|}
\hline \multirow{3}{*}{ Hypertension } & \multicolumn{4}{|c|}{ Stroke } & \multirow[b]{2}{*}{ Total } & \multirow[b]{2}{*}{$\%$} \\
\hline & & SH & & & & \\
\hline & $\mathbf{F}$ & $\%$ & $\mathbf{F}$ & $\%$ & & \\
\hline Normal & 1 & 1.6 & 0 & 0 & 1 & 1.6 \\
\hline Pra Hypertension & 1 & 1.6 & 0 & 0 & 1 & 1.6 \\
\hline Hypertension Lv.1 & 0 & 0 & 3 & 4.8 & 3 & 4.8 \\
\hline Hypertension Lv.2 & 18 & 29 & 39 & 63 & 57 & 92 \\
\hline Total & 20 & 32.2 & 42 & 67.8 & 62 & 100 \\
\hline
\end{tabular}

3. Cross Tabulation and Spearman Rank statistical test results based on the correlation of blood cholesterol levels and hypertension

\begin{tabular}{|c|c|c|c|c|c|c|}
\hline \multirow{2}{*}{ Hypertension } & \multicolumn{4}{|c|}{ Kolesterol } & \multirow{2}{*}{ Total } & \multirow{2}{*}{$\%$} \\
\hline & \multicolumn{2}{|r|}{ Normal } & \multicolumn{2}{|c|}{ High } & & \\
\hline & $\mathbf{F}$ & $\%$ & $\mathbf{F}$ & $\%$ & & \\
\hline Normal & 1 & 1.6 & 0 & 0 & 1 & 1.6 \\
\hline Pra Hypertension & 1 & 1.6 & 0 & 0 & 1 & 1.6 \\
\hline Hypertension Lv.1 & 1 & 1.6 & 2 & 3.2 & 3 & 4.8 \\
\hline Hypertension Lv.2 & 26 & 42 & 31 & 50 & 57 & 92 \\
\hline \multirow[t]{2}{*}{ Total } & 29 & 46.8 & 33 & 53.2 & 62 & 100 \\
\hline & \multicolumn{4}{|c|}{$p=0.004$} & \multicolumn{2}{|c|}{ Rho $_{x y}=0.129$} \\
\hline
\end{tabular}




\section{DISCUSSIONS}

Correlation of Blood Cholesterol Levels with Stroke incidents. The results of this study indicate that there is a correlation between blood cholesterol levels and the incidence of stroke with a value of $\rho$ value of $0.004(\rho<0.05)$. High total cholesterol levels are one of the modifiable risk factors that can cause an ischemic stroke (Sofyan, 2015). High total cholesterol levels can cause atherosclerosis, which is a basic pathology in the occurrence of non-hemorrhagic ischemic stroke or stroke (Muhammad, 2012). High total cholesterol levels can be found in $19 \%$ of total patients with ischemic stroke, and has been shown to be an independent predictor for patients with ischemic stroke or non-hemorrhagic stroke. Low total cholesterol levels are associated with microaneurysms that can cause intracerebral hemorrhage (ICH). According to Heni (2011), there is an inverse correlation between total cholesterol levels and the incidence of hemorrhagic stroke. This is attributed to the function of cholesterol in strengthening and stabilizing blood vessel walls, especially when the blood vessel wall requires greater strength to withstand high blood pressure.

Correlation of Hypertension with Stroke incidents. The results of this study indicate that there is a correlation between hypertension and the incidence of stroke with a value of $\rho$ value of $0.031(\rho<0.05)$. The results of this study are supported by previous studies that most hypertensive individuals have a stroke (Sofyan, 2015).Hypertension will stimulate the appearance of plaque deposits in large blood vessels (atherosclerosis). Plaque deposits will narrow the lumen / diameter of blood vessels. Unstable plaque will easily break and detach. Plaques that are released increase the risk of blocking the blood vessels of the brain that are smaller. When this happens, it will cause stroke (Rizaldy, 2010). Therefore, the results of the analysis showed that hypertensive individuals had a greater proportion of individuals who had a stroke compared with individuals who did not have a stroke. This is consistent with the results of a study that showed the proportion of hypertensive individuals who had a stroke was greater than those who did not have a stroke.

Hypertensive individuals tend to have a stroke because hypertension is the most influential risk factor for stroke incident. The risk that most contributes to the incidence of stroke is hypertension. Hypertension can cause weak blood vessels to rupture. If this happens to a blood vessel in the brain, there is bleeding in the brain which can result in death. Stroke can occur due to blockages of blood clots that do not flow smoothly in the narrowed vessels (Vitahealth, 2004).Hypertension therapy is not only through pharmacological therapy but there are non pharmacological therapies such as herbs or herbal medicine. According to Negara (2017) in his research found that giving 200 grams of cucumber juice in $100 \mathrm{ml}$ of water can reduce hypertension.

Correlation of Blood Cholesterol Levels with Hypertension. The results of this study indicate that there is no correlation between blood cholesterol levels with hypertension with $\mathrm{p}$ value of 0.129 ( $\mathrm{p}<0.05)$. For that reason blood cholesterol levels are not always the cause of hypertension because an increase in blood pressure / hypertension can be caused by several factors such as stress, lifestyle, diet, age, occupation, education, obesity, and others. According to Sallika (2010) not all hypercholesterolemia sufferers experience hypertension and not all people with hypertension suffering from hypercholesterolemia, but high blood cholesterol levels tend to increase blood pressure. People who are most at risk of having high cholesterol levels are those who adopt a diet that contains high saturated fats such as those found in fish, butter, cheese, and cream will increase levels of Low Density Lipoprotein (LDL) cholesterol in the blood.

The results of this study are in line with Irdawati (2010) research showing the results of the calculated $\rho$ value of 0.409 and $p$-value $(0.013)<0.05=$ Ho so that it is rejected and Ha is accepted meaning that there is a correlation between stress levels and blood pressure. Stress with blood pressure is thought to be via the sympathetic nerve, which can gradually increase blood pressure. Stress or mental tension (feeling depressed, moody, anxious and pounding and vengeance) can stimulate the adrenal hormone and stimulate the heart to work faster and stronger, so that blood pressure will increase.

This research was also supported by Aisyah (2013) using Person shows $r$ count of 0.843 and $p$ value of 0.00 so Ho is rejected and $\mathrm{Ha}$ is accepted which means that there is a correlation between sleep quality and blood 
pressure. The calculated $\mathrm{r}$ value of 0.843 indicates that the correlation shows a strong level of correlation. This research is also in line with the research of Mahendra (2014) which shows that there is a correlation between the characteristics (education) of hypertensive patients with motivation to control blood pressure with $\rho$ value of $0.005(<0.05)$ and there is a significant correlation between the level of knowledge and motivation to control blood pressure with $\rho$ value $0,000 \quad(<0.05)$. The research can show that a person's characteristics and knowledge related to motivation to keep control of blood pressure. Someone who has high cholesterol levels does not always experience an increase in blood pressure. Cholesterol is not always a cause of stroke, many events also stroke with normal cholesterol. according to research conducted by Aisyah (2013) found that there is a relationship between age and hypertension with the incidence of stroke, while gender is not related to the incidence of stroke.

Generally high blood pressure (hypertension) is always together with an increase in high blood cholesterol. In a study published by the American Journal of Epidemology, people who did not eat meat (vegetarian) had blood pressure that was much lower than meat eaters. The conclusion of the study is that there are differences in the level of blood pressure both caused by consumption of protein and animal fat. The Genis study (2012) found that most $(76.5 \%)$ samples suffering from hypercholesterolemia had high fat intake. Types of fat consumed include: coconut oil, thick coconut milk, fatty meat and innards. The results of statistical tests using Person Chi Square obtained $p$ value $0.016(<0.05)$ so that it can be concluded that there is a significant correlation between consumption of saturated fat and the incidence of hypercholesterolemia.

Correlation of Blood Cholesterol Levels and Hypertension with Stroke Events.From the results of the study using linear regression test found that between blood cholesterol levels with a mean value of 0.453 and hypertension with a mean value of 0.994 so the most dominant with the incidence of stroke is hypertension. Where hypertension (high blood pressure) is the most important risk factor based on the degree of risk of stroke. Whereas according to the study of Sorganvi et al (2014) hypertension is the greatest risk of stroke compared to family history of stroke and smoking status.

Hypertension will spur the onset of plaque in large blood vessels (atherosclerosis).Hypertension must be treated not only from yourself but from the family plays a big role, according to research conducted by the Negara (2018) found that dischard planning has a significant influence on hypertensive patients.

The appearance of plaque will narrow the lumen or diameter of the blood vessels. Unstable plaque will easily break and detach. Plaques that are released increase the risk of blocking the blood vessels of the brain that are smaller. When this happens, a stroke arises. And so does hypercholesterolemia (excess cholesterol levels) is a risk factor for stroke in someone. Hypercholesterolemia is a condition that shows low levels of lipoprotein (LDL) in the blood that exceeds normal, so that it can lead to the formation of plaques in blood vessels which are getting more and more accumulated so that blood flow to the brain can be disrupted. If blood flow is disrupted, a stroke will occur.

\section{CONCLUSIONS}

Based on the results of research conducted by researchers, the results of this study can be concluded:Correlation between Blood Cholesterol Levels and Stroke Events has a significant correlation in statistical tests with $\mathrm{p}$ value 0.004 .The correlation of hypertension with stroke events has a significant correlation in statistical tests with $p$ value 0.031 .The correlation between blood cholesterol levels and hypertension does not have a significant correlation in statistical tests with $\mathrm{p}$ value 0.129.Relation of Blood Cholesterol Levels and Hypertension with Genesis found that between blood cholesterol levels with a mean value of 0.453 and hypertension with a mean value of 0.994 so that the most dominant with the incidence of stroke is hypertension. 


\section{REFERENCES}

Aisyah, Muhrini, Sofyan., Ika, Yulieta M. Sihombing., Yusuf, Hamra., (2013). Hubungan Umur, Jenis Kelamin dan Hipertensi dengan Kejadian Stroke pada pasien Rawat Inap di Rumah Sakit Umum Provinsi Sulawesi Tenggara Tahun 2012. Jurnal Hasil Penelitian. Kendari: Fakultas Kedokteran Universitas Haluoleo.

Arifianto, Aji Seto., sarosa, Moechammad and Setyawati, Onny., (2014). Klasifikasi Stroke Berdasarkan Kelainan Patologis dengan Learning Vector Quantization. Jurnal EECCIS Vol. 8, No.2.Diakses pada tanggal 17 maret 2019. Available from

http://www.jurnaleeccis.ub.ac.id/index.p hp/eeccis/article/view/248/218.

American Hearth Association's Annual Scientific Sessions., (2017). Hypertension Guidelines Programming. Anaheim California. Diakses pada tanggal 13 november 2019. Available from

https://whitecoathunter.com/pedomanhipertensi-aha-2017.

Anies., (2018). Penyakit Degeneratif: Mencegah dan Mengatasi Penyakit Degeneratif dengan Perilaku dan Pola Hidup Modern yang Sehat. Yogyakarta: Ar. Ruzz Media.

Burhanudin, M., (2012). Faktor Risiko Kejadian Stroke Pada Dewasa Awal (1840 Tahun) di Kota Makassar Tahun 2010-2012. Makassar: Universitas Hasanuddin.

Dinas Kesehatan Provinsi Kalimantan Selatan, (2012). Profil Kesehatan Provinsi Kalimantan Selatan Tahun 2012. Banjarmasin: Dinas Kesehatan Provinsi Kalimantan Selatan. http://www.depkes.go.id.

Endang, Lanywati., (2011). Diabetes Mellitus Penyakit Kencing Manis. Yogyakarta: KANISUS Media.

Heni, Maryati., (2017). Hubungan Kadar Kolesterol dengan Tekanan Darah Penderita Hipertensi Di Dusum Sidomulyo Desa Rejoagung Kecamatan
Ploso Kabupaten Jombang. Jurnal EISSN Vol. 8, No.2. Diakses pada Juli 2017. Available from http://ejournal.umm.ac.id/index.php/kep erawatan/issue/view.

Muhammad, Anwar, Hafid., (2012). Hubungan Riwayat hipertensi dengan Kejadian Stroke di RSUP Dr. Wahidin Sudirohusodo. Jurnal Hasil Penelitian. Makassar: Program Studi Ilmu Keperawatan Fakultas Ilmu Kesehatahn UIN Alauddin Makassar.

Negara, C. K., Erna, E., \& Anna, A. (2018). The Effect of Cucumber Juice (Cucumis Sativus) Toward Hypertension of Elderly at Tresna Werdha Budi Sejahtera Social Institution of Banjarbaru South Borneo 2017. IJNP (Indonesian Journal of Nursing Practices), 2(1), 16-21.

Negara, C. K. The Effect of Discharge Planning on Treatment Adherence among The Elderly with Hypertension in Banjarmasin, South Kalimantan. In 4th International Conference on Public Health 2018 (pp. 237-237). Sebelas Maret University.

Pandian, JD and Sudhan, P., (2013). Stroke Epidemiology and Stroke Care Services in India. Journal of Stroke.

Rahayu., (2014). Faktor Risiko Penyebab Meningkatnya Kejadian Stroke Pada Usia Remaja dan Usia Produktif. Berkata Epidemiologi.

Rizaldy, P., (2010). Awas Stroke. Yogyakarta: PT. Andi.

Sallika., (2010). Serba Serbi Kesehatan Perempuan. Jakarta: Bukune.

Sofyan, AM., Sihombing, IY., Hamra and Yusuf., (2015). Hubungan Umur, Jenis Kelamin, dan Hipertensi dengan Kejadian Stroke. UHO.

Sorganvi, V., Kulkarni, MD., Kadeli, D and Athargas, S., (2014). Risk Factors For Stroke: A Case Control Study. International Journal of Current Research And Review.

Vitahealth., (2004). Hipertensi: Informasi Lengkap Untuk Penderita dan Keluarganya. Jakarta: PT. Gramedia Pustaka Utama. 